\title{
Paraguay, Bhutan and Nepal: Landlocked but Hydropower Rich Cases of the Lame Duck, Flying Goose and Sitting Duck!
}

\author{
S.B. Pun
}

Abstract: Paraguay has 5.6 million people, Bhutan has 0.6 million and Nepal has 27 million, all small land locked
countries with rich hydropower potential. The 12,600 MW Itaipu Project commissioned on Paraguay-Brazil border
river, Parana, was the world's largest hydropower plant until China's Three Gorges superseded it in 2007. Paraguay's
share, half of Itaipu's generation, is on average of about 44,000 million units annually with over $90 \%$ sold to Brazil.
Nepal's projected average annual generation from three major multipurpose projects, at Sapta Koshi, Karnali Chisapani
and Pancheshwar's $50 \%$, totals about the same. Despite two decades of such large volume of power export, however,
Paraguay remains the second poorest country in South America. Nepal, with a tiny $550 \mathrm{MW}$ of hydropower capacity, is
undergoing bouts of load shedding and is mired in controversies. Bhutan, with a mere export of about $1,300 \mathrm{MW}$,
comprising $60 \%$ of the national revenue, has therefore been strongly recommended as the model for Nepal to replicate.

If India is to maintain her 9\% GDP growth rate then she will require 785,000 MW (6 times the present installed capacity) of power by $2026 / 27$. Along with this demand for power, she will also need huge quantities of additional freshwater. While there are options for power, there are none for water. All large or small storage projects in Nepal augment water to the rivers flowing down to India. So far India's policy has been to obtain this augmented water through Nepal's default. Nepal needs to seriously consider why Paraguay, despite its huge export, is a lame duck while Bhutan with a tiny export is a flying goose!

Key words: Power export, Karnali Chisapani, Pancheshwar, Sapta Koshi, Nepal-India Water Resources negotiations, Nepal's default, Paraguay, Bhutan

\section{Foreword}

Gor the last 50 years, those at the helm of Nepalese 1 affairs, from Panchas to Democrats to Comrades, have all been wailing over our "apar khera gai rakheko pani" ("infinite waste of water"). In fact, the Nepali Congress by "implementing large, medium and small projects including Upper Tamakoshi, West Seti, Arun III, Upper Karnali" (NC 2007) within the coming 10 years plan to increase generation capacity ten fold to $5,000 \mathrm{MW}$ and earn "billions of foreign currency" through power export. Not to be outdone, the CPNMaoist similarly declared that "through short and long term plans" 10,000 MW generation capacity (twenty fold) will be added within the next 10 years (CPN-M 2007). Surprisingly, the CPN-UML was not that euphoric and had a far more sobered tone advocating a policy of multiple uses on storage projects, domestic capital for medium projects and "local participation for projects under $10 \mathrm{MW"}$ (CPN-UML 2007).

Globalization and liberalization brought to the fore the charms and greed of market forces. Our getrich-quick Nepalese do not want to 'miss the boat' and are lobbying hard for Nepal to replicate the Bhutan model of hydropower development. It is in this context that the land-locked and hydropower rich countries, Paraguay and Bhutan, need to be visited so that Nepal may, perhaps, learn a few lessons. By sheer coincidence, these three landlocked countries have all undergone dramatic political changes recently. After an 18-year democratic parliamentary exercise and the 10-year CPN-Maoist insurgency, Nepal's
Constituent Assembly is set to re-write another constitution. Bhutan's 'Gross National Happiness', the Drukpa monarch's concept, now resides with that country's democratically elected parliament. In faraway Paraguay, the party led by the left leaning former bishop, Fernando Lugo, finally voted out the 63-year rule of the Colorado party.

\section{Paraguayan geopolitics}

Paraguay, with a 5.6 million population, is a small landlocked but hydropower rich South American country sandwiched between two large neighbors, Portuguese-speaking Brazil to the north and east and Spanish-speaking Argentina to the south. Traditionally, Paraguay was very dependent both economically and politically to its southern neighbor, Argentina. Her only outlet to the sea was along the Parana river via an Argentine port. Historically, there was keen rivalry between Argentina and Brazil to exert influence over Paraguay. In 1966 Paraguay signed the Treaty of Iguacu with Brazil to develop the border river, Parana. The treaty basically recognized the border river's common ownership of water with equal sharing of hydropower. This was followed in 1973 with the signing of Itaipu treaty for the construction of the world's then largest 12,600 MW Itaipu hydropower plant on Parana. ${ }^{1}$ In order to woo Paraguay, Brazil built a bridge over Parana to provide an alternate route to a sea port in Brazil. Paraguay was thus freed from Argentina's clutch over access to the sea. 
Not to be outdone, in that same year, 1973, under the personal instruction of President Peron "to sign now and renegotiate later", Argentina signed the Yacyreta Treaty with Paraguay to develop the 2,700 MW hydropower. Thus, hydropower development for export became Paraguay's main national agenda, an agenda not dissimilar to that of our main political parties, the CPN-Maoist and Nepali Congress.

\section{Itaipu dam controversies}

The 12,600 MW Itaipu dam was embroiled in a host of controversies between the two countries: ${ }^{2}$ on the 196 meter height of the dam, on disproportionate extent of flooding between the two countries, on low compensation for land, on 50 cycle frequency for Paraguay's share of the 6,300 MW generators when $90 \%$ of it is for export to Brazil with 60 cycle frequency and even on the structure of the Itaipu Binacional Administration. But the main debate within Paraguay was on what to do with this huge 6,300 MW of its share of power at a time when its own installed capacity was $235 \mathrm{MW}$, just one-third of the $700 \mathrm{MW}$ single unit to be installed there. Incidentally, Nepal's much vaunted "sun to rise from the west"3 Pancheshwar has a similar 6,480 MW capacity with 3,240 MW as Nepal's share.

One school of thought in Paraguay lobbied against export to maximize domestic use through industrialization and installing energy intensive industries within the country. The other school lobbied for export, a situation not dissimilar to Nepal. The export lobby won because Paraguay had poor infrastructure, no domestic raw materials and, above all, no financial resources that, once the export revenue starts accruing (the lobbyists argued), could be ploughed back into industrialization and infrastructure building. The initial project cost estimate of US\$ 2 billion in 1973 snowballed to US $\$ 18$ billion when completed in $1985 .{ }^{4}$ Similarly, Yacyreta's original estimate of US $\$ 2.7$ billion also soared to US $\$ 11.5$ billion, forcing former Argentine President, Carlos Menem, to term Yacyreta "a monument to corruption".

\section{Lame duck}

Because of the Paraguayan parliament's demand, early on, for a fair share of the project's contracts, officially $50 \%$ of all major contracts were earmarked for Paraguay. In practice, Paraguay's small industrial sector was no match for Brazil's technologically advanced and capital-wise strong industries. Over $75 \%$ of the total contracts with key inputs like steel, cement, machineries, etc., were all supplied by Brazil. Even minor items like housing materials for Paraguayan workers came from Brazil.

But Paraguay failed dismally on the price of electricity negotiated with Brazil. As the monopoly buyer, Brazil gave Paraguay an extremely paltry price of US\$300 per million units; i.e., 0.03 cents US per unit. This scenario was inevitable, as Paraguay did not have the capacity to bear her portion of the project cost and Paraguay had to approach Brazil for the loan. ${ }^{5}$ Despite many revisions and heavy tariff increases, the price, after all 18 units were commissioned in 1992, still became only US $\$ 4,200$ per million units; i.e., a mere 0.42 cents US per unit.

Itaipu's average annual generation over the 16 years from 1992 to 2007 is 82,038 million units, of which Paraguay's half entitlement is 41,019 million units (MU). ${ }^{6}$ By comparison, the average annual generation from Nepal's planned three largest multipurpose projects (10,800 MW Karnali Chisapani at 20,842 MUs; 6,480 MW Pancheshwar at 6,166 MUs, half of 12,333 MUs; and 3,00o MW Saptakoshi at 17,607 MUs) totals 44,615 million units, just about Paraguay's share at Itaipu. At 0.42 cents US per unit, Paraguay's export to Brazil brought her a paltry US\$ 172 million annually. That is why Paraguay, despite over two decades power export from Itaipu, is still the second poorest country in South America (after Bolivia). That is also why Paraguay's new left-leaning president, Fernando Lugo, is rattling his saber to end the contractual obligations with Brazil of selling power below the commercial market price. Paraguay, despite its earlier self-thought clever political maneuvering, now feels that it has been cheated and got a raw deal from Brazil. ${ }^{7}$

The simple lesson for the Nepalese is that megawatts and millions of units for export do not necessarily translate into 'arabs' of hard Indian currency. ${ }^{8}$ For the 'sun to rise from the west' Nepal must have in place sound in-house institutions that can negotiate the intricacies of "cost of project in proportion to the benefits accrued, power benefit, inter alia, saving in costs as compared with relevant alternatives, etc." The tiny 5.6 million Paraguayans have a per capita income of only US\$ 1,100 whereas the huge 176.6 million Brazilians have a per capita income of 2,710 US\$ (World Bank 2005). Thus, Paraguay is a classic case of the lame duck!

\section{Bhutanese geopolitics}

In 1949, Bhutan signed a treaty with India wherein Bhutan's external relations were "to be guided by the advice of the Government of India" and import of "arms, ammunition, machines, warlike materials or stores" could only be done with India's "assistance and approval."9 The Sino-Indian border clash of 1962 taught India to build for its own security a series of road networks along the Sino-Indian border in Ladakh, NEFA and even Bhutan. These roads provided access to the difficult interior terrain of Bhutan, not only for socio-economic activities but also for better hydropower sites. The 1975 annexation of the Sikkim kingdom by India, on the premise of bowing to the wishes of the majority, was undoubtedly a wake-up call for both the kingdoms of Bhutan and Nepal. 
While Bhutan immediately got down to invoke new citizenship laws, Nepal's 'permit system', recommended by Dr. Harka Gurung, was termed antinational. Bhutan enacted the 1985 citizenship act and based on the 1988 census claimed her population to be only $600,000 .^{10}$ Bhutan then aggressively launched her Bhutanization drive of one language, one religion and one set of social customs. This resulted in the cleansing of 'Lhotsampas', the southerners of Nepalese origin, who flocked into Nepal through Indian territories. The seven refugee camps in east Nepal's Jhapa and Morang Districts house over 106,000 Bhutanese, languishing for the last 18 years. Without the tacit nod from India plus Nepal's dismal diplomacy, Bhutan could not have remained stubborn over such lengthy periods on such a sensitive humanitarian issue. ${ }^{11}$

\section{Flying goose}

Bhutan has about 30,000 MW hydropower potential of which 16,000 MW is estimated to be economically exploitable. With $60 \%$ grant and $40 \%$ loan at a $5 \%$ interest rate from India, the 336 MW Chukha Hydropower Project was commissioned in 1988. Similarly, the IRs 41,240 million 1,020 MW 4,865 million units Tala Hydropower Project had the same grant and loan ratio with interest rate hiked up to $9 \% .{ }^{12}$ Commercial operations of Tala started from July 1, 2006 and the first payment on the loan, repayable in 12 equal installments, started from July 31, 2006. This is the Bhutan model of hydropower development with the consultants, contractors, electro-mechanical equipments, steel, cement, etc., all coming from the loan provider. Over $95 \%$ of the cheap power so generated is fed back to Indian grids to drive Indian industries so that the goods and services India produces will be far more competitive both regionally and globally. ${ }^{13}$

With Tala's commissioning, Bhutan's power export is expected to generate about US $\$ 1$ million a day. ${ }^{14}$ GDP growth, $10 \%$ in 2006, is forecasted to rise to $12 \%$ in 2007. Similarly revenue from hydropower to the national budget is expected to rise from the current $45 \%$ to $60 \%$. The current account deficit should then move to surplus in 2007. With the India-financed 45 MW Kurichu project and the Austria-financed 60 MW Basochu project, Bhutan in 2008 has a total installed capacity of about 1,465 MW. The 2003 per capita income of US\$ 660 is predicted to double from Tala's revenues (World Bank 2005). Many predict that Bhutan is, thus, well on the way to become the flying goose of South Asia. But some analysts question whether India will remain a silent spectator when Bhutan becomes an island of prosperity in a region that is increasingly facing the brunt of demographic pressure.

\section{Nepalese geopolitics}

During the critical decade of the 1950s, several things came in quick succession to Nepal: the 1950 IndoNepal Treaty of Peace and Friendship, ${ }^{15}$ the 1952 Indian Military Liaison Group to train the Nepal Army, 17 India-manned wireless checkposts on the SinoNepal border, the Tribhuvan Rajpath (highway) linking Kathmandu to the plains, the 1954 Koshi and 1959 Gandak river agreements. The furor over these agreements in Nepal and the subsequent 1964 Gandak Amendment and 1966 Koshi Revision were possible only after the short but embarrassing 1962 Sino-Indian border clash. Our two big neighbors then vied ${ }^{16}$ for spheres of influence in our infrastructure construction vis-à-vis the $21 \mathrm{MW}$ Trishuli and $1 \mathrm{MW}$ Phewa projects versus the 10 MW Sunkoshi and 1.5 MW Seti projects, the Tribhuwan Rajpath versus the Arniko Rajmarg, and the Siddhartha Rajmarg into Pokhara versus the Prithwi Rajmarg from Kathmandu. Stung by its infrastructure lapses in the Ladakh and NEFA regions, India went on to build the major portion of Nepal's east-west Mahendra Rajmarg to cater to its own security concerns. This concern was manifested, in an undiplomatic manner, when Nepal was forced to retract its global tender award of the Asian Development Bank financed Kohalpur-Banbasa Road from a Chinese contractor due to vehement objections from India. The ambitious Dhankuta-KathmanduPokhara-Surkhet hill road that India had agreed to in principle remained, unfortunately, on the drawing board only. This road would have contributed greatly, both for the social-economic upliftment of rural Nepal as well as opening up access to better hydropower sites.

With the arrival of the powerful multilateral and bilateral institutions into Nepal from the 1970s, the rivalry between our two big neighbors diminished. In fact, India, while keeping the bilateral dialogues intact on the Karnali Chisapani and Pancheshwar projects, retracted to its own territory by constructing unilaterally a host of such large structures like the Girijapur barrage on Karnali river, the Tanakpur barrage on the Mahakali river and the Laxmanpur barrage on the Rapti river. Much in the fashion of the 1950 treaty, when Nepal's chips were down, India in 1990 proposed a draft Agreement on Mutual Cooperation (Bhasin 1994) to the (then) tottering Panchayat government of Nepal. In essence, besides not entering into "any military alliance with any other State" and "consult and enter into suitable protocols with the Government of India concerning the acquisition by Nepal of arms, ammunition and other materials", on natural resources development India continued on with the "shall give first preference to the Government or the nationals of India". The new and singularly important element of the draft on "the 
commonly shared rivers" was the clause: "plan new uses or projects subject to the protection of existing uses on the rivers." ${ }^{17}$ Unlike Mohan Shumsher, King Birendra refused to sign this draft Agreement with India and opted rather to become a constitutional monarch in a democratic parliamentary system.

\section{Sitting duck}

Nepal's four large rivers (the Koshi, Gandak, Karnali and Mahakali) and five medium rivers (Kankai, Kamala, Bagmati, West Rapti and Babai) contribute an overwhelming $75 \%$ of the lean season flow into the Ganges at Farakka. In 2003, the Ganges basin supported a population of nearly 513 million peoplecomprised of 25 million from Nepal, 447 million from India (42\% of India's total population of 1,064 million), and 41 million from Bangladesh (of 138 million total). At 1,061 persons per square kilometer, Bangladesh has the unique distinction of having the highest population density in the world. ${ }^{18}$ West Bengal (at 904 persons $/ \mathrm{km}^{2}$ ) and Bihar (at 880 persons $/ \mathrm{km}^{2}$ ) are not far behind (2001 India Census). Nepal's 172 persons/ $\mathrm{km}^{2}$ is quite deceptive as the Terai districts of Dhanusa, Mahottari, Sarlahi, Rautahat and Bara already have population densities of around 500 persons.

Such population densities put heavy stress on natural resources, particularly water. That is why India has embarked on her ambitious IRs. 5,600 billion River Linking Project to transfer water from the wet water-surplus region of the east to her dry water-deficit region of the west. Of the 17 Himalayan river links, Nepal figures in five of them: the KoshiMechi, Koshi-Karnali, Gandak-Ganga, Karnali-Yamuna and Mahakali-Yamuna, where huge storages like Saptakoshi at Barahchhetra, Karnali at Chisapani and Mahakali at Pancheshwar would be vital elements of the River Linking Project. These three projects are expected to uproot over 150,000 Nepalese, mainly for the benefit of the people across the border (Dikshit 2005). Bangladesh has already protested strongly and Nepal appears to be satisfied with India's official stand: "We will consult Nepal when this becomes necessary" (Sarin 2004). With the Mahakali Treaty/Pancheshwar inked, the DPR study of Saptakoshi in the final stage and the agreement to 're-activate' Karnali Chisapani, Nepal has placed herself in that unenviable position of the sitting duck.

\section{Final word}

Recent constituent assembly election manifestoes in Nepal, claiming to generate 5000 to $10,000 \mathrm{MW}$ within ten years, reveal that the new Nepal's main political parties continue to be charmed with power export to India. If India is to maintain her 9\% GDP growth rate then by $2026 / 27$ she will require an estimated 785,000 MW, which is about six times the present capacity (IL\&FS n.d.). Though India has massive coal reserves and over 148,00o MW of hydro potential, she is desperately looking around for other energy sources, including: newer technologies from the Indo-US nuclear deal, gas from unstable Central Asia or from Iran, or even the military junta of Myanmar. While energy has options like coal, gas, hydro, nuclear, wind, etc., water has none. The dwindling Ganges badly needs augmentation and in the name of hydropower development in Nepal, India aims to get her freshwater by default. The $750 \mathrm{MW}$ West Seti project and the 60o MW Budhi Gandaki project, both storage type, will provide the badly needed augmented water, however little that may be. Because the Mahakali Treaty stipulates that the cost of the project will be "in proportion to the benefits accrued", the Pancheshwar project has been bogged down since 1996 with acrimony over the accrued benefits. To overcome that acrimony, India astutely proposed that the costs be in proportion to the usage from the storage created. Nepal retorted that the treaty had no such provision. Pashupati SJB Rana, Nepal's then Water Resources Minister, claimed that Nepal was able to convince India to accept the "principle of displaced cost of alternatives in the evaluation of electricity benefits." India countered that the "relevant alternatives available" could well mean other hydropower, nuclear, gas, etc., and not necessarily coal fired thermal plants that our minister had in mind. So intricate and complex have the IndoNepal negotiations on water resources development become that there were times when Nepal mistook the forest for the trees, like the 1991 MOU on Tanakpur. In our hurried quest to be the South Asian flying goose, Nepal could well land up like the lame duck, Paraguay!

Santa Bahadur Pun served in the power sector for over three decades mostly in the O\&M field. He was the former Managing Director of Nepal Electricity Authority and in his closing years served as the Officer on Special Duty at the Ministry of Water Resources. He writes on water and energy issues.

Corresponding address: santapun@ntc.net.np

\section{Notes}

1. Three Gorges Dam on Yangtze in China will have an installed capacity of 22,500 MW and as of December 2007 it already surpassed Itaipu's capacity with 14,100 MW.

2. In 2007 this capacity increased to $14,000 \mathrm{MW}$, which means that Paraguay now owns 10 units of generators each rated at $700 \mathrm{MW}$. So sensitive were the Paraguayans that they insisted on all their Itaipu generators to be of 50 cycles, their standard frequency. This forced Brazil, with 60 cycle frequency, to install frequency converters for all power to be purchased from Paraguay. 
3. Pashupati S.J.B. Rana, Water Resources Minister (at the time), exhorting the Joint Session of Parliament to ratify the Mahakali Treaty on September 11, 1996.

4. The last (18th) generator was installed in 1991.

5. A case not dissimilar to Pancheshwar project: in 1995 the project cost US\$2,980 million. There is major acrimony between Nepal and India over project benefits, particularly irrigation and flood control. Assuming Nepal's portion to be 50\%, however, then US\$ 1,490 million @ Rs65 per US\$ equates to Rs 97 $a r a b$. Nepal's internal revenue resource generation for fiscal year 2007/o8 was projected at Rs 104 arab. So do we, like Paraguay, approach India for the loan?

6. In 2005, Itaipu contributed $93 \%$ of Paraguay's and $20 \%$ of Brazil's electricity consumption.

7. Much in the manner that the Nepalese howl over the Koshi, Gandak and Mahakali treaties!

8. NRs. $21 a r a b$ annually from export of Nepal's Pancheshwar power (Rana 1995).

9. Articles 2 and 6 of the treaty inked in Darjeeling on August 8, 1949. In February 2007, the two countries "contemporised" the 57-year-old treaty that will "largely free Bhutan's foreign policy and defense purchases from New Delhi's approval" (The Telegraph, Calcutta. January 11, 2007). Also of interest to Nepal is the return of "32 square miles territory in the area of Dewangiri" to Bhutan by India (www.nerve.in/news/25350032381).

10. Until 1990 Bhutan maintained that her population was 1.2 million. But in 2004 King Wangchuk in his National Day address revised it to "just over 500,000" (Matthew, 1999).

11. It is indeed heartening to see energetic young (Nepali) Bhutanese couples from the camps in Nepal with their children boarding the aircraft at Tribhuvan international airport for better futures in USA.

12. www.thehindubusinessline.com/bline/2006/o8/ $17 /$ stories

13. The Chukha export tariff has recently been pegged at IRs. 2/unit (www.bhutannewsline.com). This price of energy needs to be equated with the recent US $\$ 135$ per barrel of oil that was in 1998 only US $\$ 12$.

14. www.adb.org/documents/books/ado/2006/bhu.asp

15. Nepal's leaders fail to stress that India, the world's largest democratic country, hastily concluded this treaty not with a democratically elected
Government of Nepal but with the decrepit century old autocratic Rana regime that, in its last dying gasps, was ready to sign on any dotted line. On the import of "arms, ammunition or warlike material" this treaty was akin to that of Bhutan requiring the "assistance and agreement of the Government of India". On the development of natural resources (not limited to Water Resources only) Nepal "shall give first preference to the Government or the nationals of India...". Now 58 years later, after having 'contemporized' her treaty with Bhutan, India is now ready to review this treaty with Nepal.

16. Much in the fashion of Paraguay's neighbors, Brazil and Argentina.

17. This clause, however, got embedded into the Mahakali treaty: "without prejudice to their respective existing consumptive uses."

18. With the exception of the city-stage of Singapore: 6,967 persons (World Bank 2005).

\section{References}

Bhasin, A.S., 1994, Nepal's Relations with India and China, Delhi: Siba Exim Pvt. Ltd.

CPN-M, 2007 [2064 VS], Manifesto for the Constituent Assembly Election, Kathmandu: CPN-Maoist Party (Community Party of Nepal-Marxist).

CPN-UML, 2007 [2064 VS], Manifesto for the Constituent Assembly Election, Kathmandu: CPN-UML Party (Community Party of Nepal-United Marxist Leninists\}.

Dikshit, A., 2005 [2062 VS], Mulyankan, Chaita/46, Kathmandu.

IL\&FS, n.d., New Delhi: IL\&FS Infrastructure Development Corporation.

Matthew, Joseph C., 1999, Ethnic Conflict in Bhutan, New Delhi: Nirala Publications

NC, 2007 [2064 VS], Manifesto for the Constituent Assembly Election, Kathmandu: Nepali Congress Party.

Rana, Pashupati S.J.B., 1995, to the Press on Ashwin 7, 2053 VS [1995], after the Mahakali treaty was ratified.

Saran, Shyam (India's Ambassador to Nepal), 2004, to the media (Spotlight magazine, Kathmandu, July 16).

World Bank, 2005, World Development Report, Washington DC: The World Bank. 